\title{
KOMBINASI METODE ANP DAN PROMETHEE DALAM MENENTUKAN PRIORITAS DISTRIBUSI LOGISTIK BENCANA ALAM
}

\author{
Mushaf $\mathbb{D}^{1)}$, Yuyun $\mathbb{D}^{2)}$, dan Wardi $\mathbb{D}^{3)}$ \\ ${ }^{1,2}$ Sistem Komputer, Pascasarjana STIMIK Handayani Makassar \\ ${ }^{3}$ Teknik Elektro, Fakultas Teknik, Universitas Hasanuddin \\ ${ }^{1,2}$ Jl. Adhyaksa Baru No. 1, Kota Makassar, Sulawesi Selatan \\ ${ }^{3}$ Jl. Perintis Kemerdekaan KM. 10, Tamalanrea Indah, Kec. Tamalanrea, Kota Makassar, Sulawesi Selatan \\ E-mail : mushafsyafar@gmail.com ${ }^{1)}$,yuyunwabula@handayani.ac.id ${ }^{2)}$,wardi@unhas.ac.id ${ }^{3)}$
}

\begin{abstract}
ABSTRAK
Bencana alam yang kerap terjadi di Indonesia menimbulkan banyak korban jiwa. Kejadian ini membuat masyarakat tergerak untuk menjadi relawan pasca bencana alam terjadi. Namun, kendala yang dialami salah satunya adalah saat pendistribusian bantuan logistik bencana alam. Tidak adanya data terpusat terkait data posko, jumlah korban, kondisi korban, dan kebutuhan korban yang dapat menjadi acuan bagi seluruh relawan membuat para relawan kesulitan menentukan tindakan untuk distribusi bantuan logistik yang menyebabkan distribusi bantuan logistik menjadi lambat dan tidak tepat sasaran. Penelitian ini bertujuan untuk membangun sistem pendukung keputusan (SPK) pendistribusian bantuan logistik bencana alam menggunakan kombinasi metode Preference Ranking Organization Method for Enrichment Evaluation (Promethee) dan Analytic Network Process (ANP). Pada penelitian ini terdapat 6 kriteria yaitu korban berdasarkan jenis kelamin, korban berdasarkan usia, korban berdasarkan kondisi, jarak, kebutuhan pokok, kebutuhan sekunder, dan relawan. Kemudian terdapat 31 total sub kriteria dari masing-masing kriteria. Sistem kemudian diuji menggunakan metode Confusion Matrix. Dari hasil pengujian, diperoleh akurasi sebesar 87,5\%. Hasil ini diharapkan dapat membantu pendistribusian bantuan logistik pasca bencana alam.
\end{abstract}

Kata Kunci: Bencana Alam, Sistem Pendukung Keputusan, Promethee, Analytic Network Process, Confusion Matrix

\section{PENDAHULUAN}

Seringnya terjadi bencana dan banyaknya korban jiwa yang ditimbulkan (BNPB, 2019) membuat sebagian rakyat indonesia tergerak untuk menjadi relawan pasca bencana alam (Utomo, dkk., 2016). Relawan pasca bencana yang biasa disebut relawan adalah seseorang atau kelompok dengan kemampuan dan kepedulian untuk bekerja membantu secara sukarela dan ikhlas dalam upaya penanggulangan bencana (BNPB, 2014). Masyarakat dan pihak non-pemerintah dapat berpartisipasi dalam berbagai bentuk kerelawanan dalam penanggulangan bencana dan pengurangan risiko bencana (Anam, dkk, 2017). Sulitnya koordinasi antara pendonor atau donatur yang memberikan bantuan dengan pemerintah sebagai penyalur bantuan (Aji, 2018) membuat distribusi bantuan logistik menjadi terhambat. Tidak adanya data terpusat terkait data posko, jumlah korban, kondisi korban, usia korban dan kebutuhan korban yang bisa dijadikan acuan bagi seluruh pihakpihak yang terlibat membuat kesulitan dalam menentukan tindakan untuk distribusi bantuan logistik. Berdasarkan masalah tersebut, maka dibuatlah suatu sistem untuk membantu pendonor bantuan atau relawan yang terlibat dalam menentukan alternatif terbaik untuk mendistribusikan bantuan logistik bencana alam.

Penelitian sebelumnya terkait penggunaan kombinasi metode untuk pencarian bobot dan penentuan alternatif terbaik telah dilakukan oleh (Polinema, dkk., 2018) dalam pengembangan aplikasi yang membantu pencarian kos di kota Malang dengan metode AHP dan Promethee. Penelitian tersebut bertujuan memudahkan pencarian kos dengan menyediakan informasi terkait data kos dan penyewaan rumah kos secara online. Penelitian lain terkait penggunaan kombinasi metode AHP dan Promethee telah dilakukan oleh (Ranti, dkk, 2020) pada analisis penentuan penginapan yang sesuai dengan kebutuhan pengunjung. Metode pencarian bobot dan penentuan alternatif terbaik juga telah dilakukan oleh (Siregar, 2017) pada penelitian terkait sistem pendukung keputusan penentuan prioritas menggunakan metode AHP-Topsis untuk dijadikan dasar penentuan strategi dalam peningkatan pengawasan wilayah perikanan dan juga oleh (Fadlan, dkk, 2017) pada penelitian terkait kombinasi metode Topsis Dan AHP pada merekomendasikan penerima beasiswa peningkatan prestasi akademik. Penelitian selanjutnya terkait penggunaan kombinasi metode untuk pencarian bobot dan penentuan alternatif terbaik telah dilakukan oleh (Sumiyatun \& Wardoyo, 2016) dalam penelitiannya terkait kombinasi metode ANP dan Topsis dalam menentukan prioritas media promosi perguruan tinggi.

Penelitian ini menggunakan metode pengembangan dari AHP yaitu ANP (Analytical Network Process) untuk penentuan bobot kriteria dan Metode Promethee untuk 
penentuan prioritas distribusi bantuan bencana. Metode promethee ini sangat cocok pada penelitian ini, dikarenakan jika dibandingkan dengan metode lain, metode ini lebih sederhana dalam konsep dan pengaplikasiannya untuk analisis multi kriteria. Metode ini digunakan pada pengambilan keputusan yang memiliki kriteria yang saling bertentangan dan alternatif dengan nilai terbesar yang nantinya terpilih sebagai alternatif terbaik (Ningsih \& Windarto, 2018). Metode Promethee adalah metode auto ranking (Farid, dkk., 2019) sehingga tidak mengabaikan alternatif-alternatif yang lain dalam hal ini posko bantuan. Metode Promethee juga dapat digunakan untuk kasus dengan jumlah kriteria yang bersifat kuantitatif dan kualitatif (Dewi, dkk., 2018) sehingga cocok digunakan pada kasus penentuan distribusi bantuan bencana yang memiliki kriteria kuantitatif seperti jumlah persediaan kebutuhan pokok, jumlah persediaan kebutuhan sekunder, jumlah korban, usia korban, jarak posko penerima bantuan ke posko-posko pengungsian, dan kondisi korban.

\section{RUANG LINGKUP}

Dalam penelitian ini permasalahan mencakup:

1. Bagaimana kriteria dan sub kriteria dalam penentuan prioritas distribusi bantuan logistic bencana alam.

2. Bagaimana penentuan alternatif terbaik dengan kombinasi metode ANP dan Promethee dalam penentuan prioritas distribusi bantuan logistik bencana alam.

3. Apakah kombinasi metode ANP dan Promethee dapat membantu pengambilan keputusan distribusi bantuan logistik bencana alam

\section{BAHAN DAN METODE}

Penelitian ini melalui beberapa tahap, dimana setiap tahapannya saling berkaitan dan juga mempengaruhi satu sama lain. Tahapan-tahapan tersebut adalah :

\subsection{Pengumpulan Informasi dan Studi Literatur}

Penelitian ini diawali dengan pengumpulan informasi dan studi literature terkait metode ANP dan Promethee. Informasi mengenai bencana alam yang akan dijadikan bahan analisis diperoleh dari BPBD Provinsi Sulawesi Selatan dan BPBD Kabupaten Gowa. Informasi yang dikumpulkan berupa kriteria, sub kriteria, dan informasiinformasi seputar pendistribusian bantuan logistik pasca bencana.

\subsection{Perancangan Sistem dan Interface}

Perancangan sistem adalah tahapan dimana desain sistem yang akan dibangun dibuat, perancangan yang dibuat berupa Use case diagram, Activity Diagram, Class Diagram, dan perancangan Interface (antarmuka). Rancangan system dibuat berdasarkan informasi yang berhasil dikumpulkan.

\subsection{Implementasi Metode ANP dan Promethee}

Tahap ini adalah tahap pengimplementasian metode ANP dan Promothee berdasarkan data-data yang telah dikumpulkan dan rancangan sistem yang telah dibuat. Metode ANP adalah metode yang menghubungkan antara kelompok atau individu pada tingkat hierarki yang berbeda serta menghubungkan antara kriteria dan sub kriteria agar hasil yang diperoleh akurat dan efisien. Metode Analytic Network Process (ANP) merupakan pengembangan metode Analytic Hierarchy Process (AHP) (Azhar \& Destari, 2019). Metode Promethee merupakan sebuah metode yang digunakan dalam penentuan urutan atau prioritas penilaian dengan multi kriteria. Metode ini digunakan karena perhitungannya yang fleksibel dan sederhana kepada pembuat keputusan (Apriliani \& Somantri, 2019).

Pada Gambar 1, flowchart tahapan penentuan prioritas distribusi bantuan bencana alam:

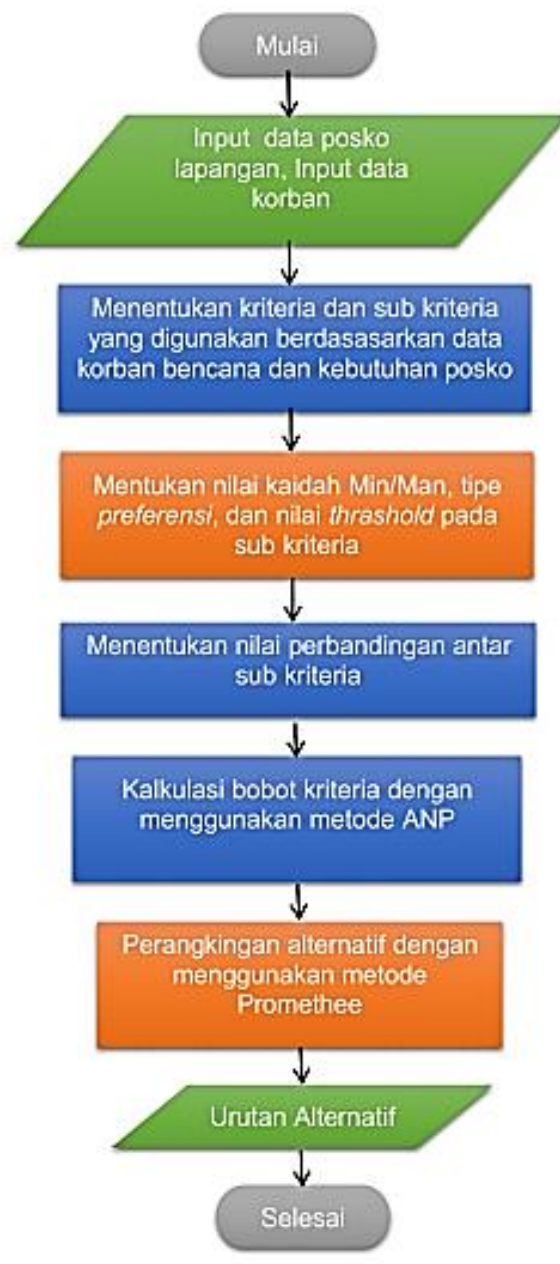

\section{Gambar 1. Flowchart Tahapan Penentuan Alternatif Prioritas Bantuan Logistik Bencana Alam}

Berdasarkan flowchart tersebut, tahap pertama yang dilakukan adalah memasukan data alternatif yaitu data posko lapangan dan data korban yang akan dievaluasi untuk penentuan alternative terbaik pada metode 
Promethee. Selanjutnya adalah menentukan kriteria dan sub kriteria. Dari hasil pengumpulan data pada BPBD Kabupaten Gowa, terdapat 6 kriteria dan 31 sub kriteria yang akan disebutkan. Selanjutnya yaitu menentukan kaidah $\min / \max$, tipe preferensi, dan threshold untuk masing-masing sub kriteria.

Proses Selanjutnya adalah penentuan nilai perbandingan antar sub kriteria dilakukan berdasarkan skala rasio pengukuran 1-9 yang dikembangkan oleh Saaty yang dapat dilihat pada tabel 1 .

Tabel 1. Preferensi Skala Saaty's 1-9 Untuk AHP.

\begin{tabular}{|c|c|}
\hline $\begin{array}{c}\text { Tingkat } \\
\text { Kepentingan }\end{array}$ & Definisi \\
\hline 1 & Sama Penting \\
\hline 3 & Sedikit Lebih Penting \\
\hline 5 & Lebih Penting \\
\hline 7 & Sangat Penting \\
\hline 9 & Mutlak Sangat Penting \\
\hline $2,4,6,8$ & $\begin{array}{c}\text { Jika elemen memiliki salah satu angka } \\
\text { diatas ketika dibandingkan elemen } \mathrm{j}, \\
\text { maka j memiliki kebalikannya ketika } \\
\text { dibanding elemen i }\end{array}$ \\
\hline
\end{tabular}

Sumber : (Nugraha \& Cholissodin, 2018)

Pada penentuan bobot kriteria dengan perhitungan metode ANP menggunakan hasil dari perbandingan sub kriteria berdasarkan skala Saaty akan di normalisasi dengan membagi nilai perbandingan antar sub kriteria dengan jumlah total sub kriteria pada masing-masing sub kriteria. Setelah itu, menentukan Eigen vector masingmasing sub kriteria dengan menjumlahkan seluruh hasil perbandingan kriteria yang sudah di normalisasi dengan jumlah sub kriteria. Terakhir adalah menentukan bobot local priority yang akan dijadikan bobot kriteria pada perhitungan metode Promethee dengan melakukan perkalian antara bobot perbandingan sebelum di normalisasi dengan Eigen vector pada masing-masing sub kriteria.

Setelah menentukan kaidah $\min / \max$, tipe preferensi, dan threshold pada masing-masing sub kriteria, tahapan penentuan alternatif terbaik menggunakan metode Promethee akan dilanjutkan dengan menentukan deviasi berdasarkan perbandingan berpasangan dengan persamaan (1)

$d_{j}(a, b)=f(a)-f(b)$

Tahapan Selanjutnya adalah menghitung index preferensi global dengan persamaan (2)

$\varphi(a, b)=\sum_{n-1}^{j} P_{J}(a, b) W_{j}(a, b), \forall a, b \in A$
Dimana $\varphi(a, b)$ dengan $a$ lebih besar dari $b$ (antara 0 hingga 1) didefenisikan sebagai jumlah bobot $P(a, b)$ pada setiap sub kriteria, dan $W_{j}$ adalah bobot yang berhubungan dengan kriteria ke- $J$. Selanjutnya adalah menghitung leaving flow dan entering flow untuk setiap alternatif. menghitung leaving flow (3)

$\phi^{+}=\frac{1}{n-1} \sum_{\chi \in A} \phi(a, \chi)$

untuk menghitung entering flow (4)

$\phi^{-}=\frac{1}{n-1} \sum_{\chi \in A} \phi(\chi, a)$

Dimana $\phi(a, \chi)$ bearti preferensi alternatif $a$ lebih baik dari $\chi$ dan $\mathrm{n}$ menunjukkan jumlah nilai. Tahap terakhir penentuan alternative metode Promethee adalah menentukan net flow dengan persamaan (5)

$\phi=\phi^{+}(a)-\phi^{-}(a)$

Semakin kecil nilai dari entering flow dan semakin besar nilai dari leaving flow maka besar kemungkinan alternatif tersebut dipilih sebagai alternatif terbaik.

\subsection{Uji Coba Sistem}

Sistem diuji dengan data-data contoh untuk simulasi bencana alam berdasarkan arahan dari BPBD Kab. Gowa. Pengujian dilakukan pada kasus pendistribusian makanan usia lebih dari 1 tahun. Kriteria-kriteria yang dipakai adalah usia 1 - 5 tahun, usia 6-11 tahun, usia 1225 tahun, usia 26-45 tahun, usia 46-65 tahun, usia >65 tahun, jarak ke posko induk, dan jumlah stok untuk makanan usia lebih dari 1 tahun. Kriteria-kriteria ini yang kemudian akan digunakan untuk menghasilkan nilai net flow. Bobot barang atau relawan yang akan didistribusikan akan berubah yaitu dicari bobot yang paling tinggi dari kriteria yang dipakai kemudian dikali dua. Pengujian ini juga menggunakan data simulasi posko lapangan seperti pada tabel 2 .

Tabel 2. Simulasi Data Posko Lapangan

\begin{tabular}{|c|l|l|c|}
\hline No & Nama Posko & \multicolumn{1}{|c|}{ Lokasi Posko } & $\begin{array}{c}\text { Jarak Ke } \\
\text { Posko } \\
\text { Induk }\end{array}$ \\
\hline 1 & Posko I & Dusun Kalau Desa Arah & $200 \mathrm{~m}$ \\
\hline 2 & Posko II & Dusun Timboro' Desa Arah & $100 \mathrm{~m}$ \\
\hline 3 & Posko III & Dusun Warak Desa Arah & $400 \mathrm{~m}$ \\
\hline 4 & Posko IV & Dusun Anrai; Desa Arah & $1200 \mathrm{~m}$ \\
\hline
\end{tabular}

Untuk menghitung tingkat akurasi sistem digunakan metode perhitungan confusion matrix. Metode ini menggunakan tabel matriks seperti pada tabel 3 jika data set hanya terdiri dari dua kelas, kelas yang satu dianggap sebagai positif dan yang lainnya negatif (Saikin \& 
Kusrini, 2019). Nilai confusion matrix biasanya ditunjukkan dalam satuan persen $(\%)$.

Tabel 3. Confusion Matrix

\begin{tabular}{|c|c|c|c|}
\hline \multirow{2}{*}{\multicolumn{2}{|c|}{ Identifikasi }} & \multicolumn{2}{|c|}{ Predicted Class } \\
\hline & & True & False \\
\hline \multirow{2}{*}{$\begin{array}{l}\text { Actual } \\
\text { Class }\end{array}$} & True & $\begin{array}{c}\text { True Positive } \\
\text { (TP) }\end{array}$ & $\begin{array}{c}\text { False Negative } \\
\text { (FN) }\end{array}$ \\
\hline & False & $\begin{array}{c}\text { False Positive } \\
\text { (FP) }\end{array}$ & $\begin{array}{c}\text { True Negative } \\
\text { (TN) }\end{array}$ \\
\hline
\end{tabular}

Sumber : (Firmanto, 2016)

untuk mencari akurasi (6)

Accuracy $=((\mathrm{TP}+\mathrm{TN}) /(\mathrm{TP}+\mathrm{FN}+\mathrm{FP}+\mathrm{TN})) \mathrm{x}$ $100 \%$.

\subsection{Implementasi Metode ANP dan Promethee}

Tahapan terakhir yaitu implementasi metode ANP dan Promethee berdasarkan data-data kriteria dan sub kriteria yang telah diperoleh. .

\section{PEMBAHASAN}

Pada penelitian ini terdapat 6 kriteria yaitu korban berdasarkan jenis kelamin, korban berdasarkan usia, korban berdasarkan kondisi, jarak dari lokasi posko lapangan ke posko induk, kebutuhan pokok, kebutuhan sekunder, dan relawan. Kemudian terdapat 31 total sub kriteria dari masing-masing kriteria. Data kriteria dan sub kriteria ini kemudian digunakan untuk perhitungan metode ANP dan Promethee. Metode ANP pada penelitian ini adalah metode yang digunakan untuk menentukan bobot kriteria sedangkan metode Promethee digunakan dalam perhitungan untuk menentukan alternatif prioritas berdasarkan bobot kriteria hasil dari metode ANP. Metode pengujian sistem yang digunakan adalah metode confusion matrix. Metode ini membandingkan hasil keluaran sistem dengan hasil aktual dari beberapa kasus simulasi pendistribusian bantuan logistik pasca bencana alam.

\subsection{Data Kriteria dan Sub Kriteria}

Tabel 4 adalah tabel yang berisi 6 data kriteria dan 31 sub kriteria, dengan masing-masing sub kriteria telah ditentukan tipe, nilai threshold, dan bobot dari perhitungan metode ANP.
Tabel 4. Data Kriteria, Sub Kriteria, Dan Bobot Kriteria Hasil Perhitungan Metode ANP

\begin{tabular}{|c|c|c|c|c|c|}
\hline \multirow{2}{*}{ Kriteria } & \multirow{2}{*}{ Min/Max } & \multirow{2}{*}{ Tipe } & \multicolumn{2}{|c|}{ Threshold } & \multirow{2}{*}{ Bobot } \\
\cline { 3 - 4 } & & & $\mathrm{p}$ & $\mathrm{Q}$ & \\
\hline \multicolumn{6}{|l|}{ Korban Berdasarkan Jenis Kelamin } \\
\hline
\end{tabular}

\begin{tabular}{|l|c|c|c|c|r|}
\hline Laki-laki & Max & Linear & 15 & 0 & 1.0277 \\
\hline Perempuan & Max & Linear & 15 & 0 & 1.195 \\
\hline
\end{tabular}

\begin{tabular}{|c|c|c|c|c|}
\hline Usia 1 - 12 Bulan & Max & Linear & 10 & ( \\
\hline
\end{tabular}

\begin{tabular}{|l|l|l|l|l|r|}
\hline Usia 1 - 5 Tahun & Max & Linear & 10 & 0 & 2.2615 \\
\hline
\end{tabular}

\begin{tabular}{|l|l|l|l|l|l|}
\hline Usia 6 - 11 Tahun & Max & Linear & 10 & 0 & 0.8806 \\
\hline
\end{tabular}

\begin{tabular}{|lll|l|l|l|l|l|}
\hline Usia 12 & - & 25 & Max & Linear & 10 & 0 & 0.8626 \\
\hline
\end{tabular}

\begin{tabular}{|c|c|c|c|c|c|}
\hline hun & Max & Linear & 10 & ( & 0.8626 \\
\hline 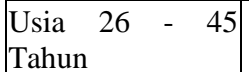 & Max & Linear & 10 & & \\
\hline
\end{tabular}

\begin{tabular}{|lll|l|l|l|r|}
\hline Tahun & & Max & Linear & 10 & 0 & 0.3869 \\
\hline Usia 46 & -65 & Max & Linear & 10 & 0 & 0.426 \\
\hline
\end{tabular}

\begin{tabular}{|l|c|c|c|c|r|}
\hline $\begin{array}{l}\text { Usia 46 - 65 } \\
\text { Tahun }\end{array}$ & Max & Linear & 10 & 0 & 0.426 \\
\hline Usia > 65 Tahun & Max & Linear & 10 & 0 & 1.4161 \\
\hline Korban
\end{tabular}

\section{Korban}

Berdasarkan

Kondisi

\begin{tabular}{|c|c|c|c|c|}
\hline Norats & & & & \\
\hline Sehat & Min & Linear & 10 & \\
\hline
\end{tabular}

\begin{tabular}{|l|l|l|l|l|r|}
\hline Sakit/Luka-luka & Max & Linear & 5 & 0 & 4.4408 \\
\hline
\end{tabular}

\begin{tabular}{|l|c|c|c|c|r|}
\hline Kritis & Max & Linear & 3 & 0 & 6.9146 \\
\hline Meninggal & Max & Linear & 3 & 0 & 6.9146 \\
\hline
\end{tabular}

Jarak

\begin{tabular}{|c|c|c|c|c|c|}
\hline $\begin{array}{lll}\text { Jarak } & \text { Ke Posko } \\
\text { Induk } & & \\
\end{array}$ & Min & Linear & 200 & 20 & 1.1737 \\
\hline \multicolumn{6}{|l|}{ Kebutuhan Pokok } \\
\hline $\begin{array}{l}\text { Makanan Usia 1- } \\
12 \text { Bulan }\end{array}$ & Min & Linear & 20 & 10 & 4.783 \\
\hline $\begin{array}{l}\text { Makanan Usia > } \\
12 \text { Bulan }\end{array}$ & Min & Linear & 90 & 30 & \\
\hline Minuman & Min & Linear & 90 & 30 & 3.7058 \\
\hline $\begin{array}{ll}\text { Pakaian } & \text { Anak } \\
\text { Laki-laki } & \\
\end{array}$ & Min & Linear & 15 & 5 & 0.720 \\
\hline \begin{tabular}{|l} 
Pakaian \\
Perempuan
\end{tabular} & Min & Linear & 15 & 5 & 1.054 \\
\hline $\begin{array}{l}\text { Pakaian Usia 1-12 } \\
\text { Bulan }\end{array}$ & Min & Linear & 15 & 5 & 1.9 \\
\hline \multicolumn{6}{|l|}{ Relawan } \\
\hline Relawan Angkut & Min & Linear & 5 & 2 & 0.398 \\
\hline $\begin{array}{l}\text { Relawan } \\
\text { Kesehatan } \\
\end{array}$ & Min & Linear & 6 & 3 & 1.674 \\
\hline \multicolumn{6}{|c|}{ Kebutuhan Sekunder } \\
\hline $\begin{array}{l}\text { Kelengkapan } \\
\text { Dapur }\end{array}$ & Min & Linear & 10 & 5 & 1.3462 \\
\hline $\begin{array}{l}\text { Kelengkapan } \\
\text { Mandi }\end{array}$ & Min & Linear & 30 & 15 & 0.6794 \\
\hline $\begin{array}{l}\text { Kelengkapan } \\
\text { Tidur } \\
\end{array}$ & Min & Linear & 8 & 4 & 1.153 \\
\hline
\end{tabular}

\subsection{Hasil Perhitungan Kombinasi Metode ANP dan Promethee}

Tabel 5 dengan nilai evaluasi yang diberikan untuk masing-masing sub kriteria pada setiap posko lapangan. 
Tabel 5. Nilai Evaluasi Alternatif Dan Bobot Kriteria Untuk Makanan Usia Lebih Dari 1 Tahun

\begin{tabular}{|c|c|c|c|c|c|}
\hline \multirow[b]{2}{*}{ Kriteria } & \multicolumn{4}{|c|}{ Alternatif } & \multirow[b]{2}{*}{ Bobot } \\
\hline & Posko I & Posko II & \begin{tabular}{|c|} 
Posko \\
III
\end{tabular} & \begin{tabular}{|c|} 
Posko \\
IV
\end{tabular} & \\
\hline \multicolumn{6}{|c|}{ Korban Berdasarkan Usia } \\
\hline Usia 1 - 5 Tahun & 0 & 4 & 0 & 0 & 2.2615 \\
\hline $\begin{array}{|lll|}\begin{array}{l}\text { Usia } \\
\text { Tahun }\end{array} & -11 \\
\end{array}$ & 3 & 3 & 5 & 4 & 0.8806 \\
\hline $\begin{array}{|lll|}\begin{array}{l}\text { Usia } \\
\text { Tahun }\end{array} & 12 & 25 \\
\end{array}$ & 8 & 26 & 30 & 10 & 0.8626 \\
\hline $\begin{array}{|lll|}\begin{array}{l}\text { Usia } \\
\text { Tahun }\end{array} & 26 & 45 \\
\end{array}$ & 8 & 26 & 34 & 11 & 0.3869 \\
\hline $\begin{array}{|lll|}\begin{array}{l}\text { Usia } \\
\text { Tahun }\end{array} & -65 \\
\end{array}$ & 1 & 10 & 9 & 5 & 0.426 \\
\hline Usia $>65$ Tahun & 1 & 4 & 1 & 2 & 1.1161 \\
\hline
\end{tabular}

\begin{tabular}{|l|c|c|c|c|c|}
\hline \multirow{2}{*}{ Kriteria } & \multicolumn{4}{|c|}{ Alternatif } & \multirow{2}{*}{ Bobot } \\
\cline { 2 - 4 } & Posko I & Posko II & $\begin{array}{c}\text { Posko } \\
\text { III }\end{array}$ & $\begin{array}{c}\text { Posko } \\
\text { IV }\end{array}$ & \\
\hline $\begin{array}{l}\text { Jarak } \\
\text { Induk Ke Posko }\end{array}$ & 200 & 100 & 400 & 1200 & 1.1737 \\
\hline $\begin{array}{l}\text { Kebutuhan Pokok } \\
\text { Makanan Usia > }>\end{array}$ & 0 & 0 & 0 & 0 & 5.72 \\
\hline
\end{tabular}

Tahapan selanjutnya perhitungan metode Promethee adalah menentukan nilai deviasi berdasarkan perbandingan berpasangan dengan menggunakan persamaan (1). Tabel 6 adalah data nilai deviasi yang diperoleh :

Tabel 6. Nilai Deviasi Berdasarkan Perbandingan Berpasangan

\begin{tabular}{|c|c|c|c|c|c|c|c|c|c|c|c|c|}
\hline \multirow{2}{*}{ Kriteria } & \multicolumn{12}{|c|}{\begin{tabular}{c|c} 
& Deviasi \\
\cline { 2 - 3 }
\end{tabular}} \\
\hline & $\mathrm{d}(1,2)$ & $\mathrm{d}(1,3)$ & $\mathrm{d}(1,4)$ & $\mathrm{d}(2,1)$ & $\mathrm{d}(2,3)$ & $\mathrm{d}(2,4)$ & $\mathrm{d}(3,1)$ & $\mathrm{d}(3,2)$ & $\mathrm{d}(3,4)$ & $\mathrm{d}(4,1)$ & $\mathrm{d}(4,2)$ & $\mathrm{d}(4,3)$ \\
\hline \multicolumn{13}{|l|}{ Korban Berdasarkan Usia } \\
\hline Usia 1 - 5 Tahun & -4 & 0 & 0 & 4 & 4 & 4 & 0 & -4 & 0 & 0 & -4 & 0 \\
\hline Usia 6 - 11 Tahun & 1 & -1 & 0 & -1 & -2 & -1 & 1 & 2 & 1 & 0 & 1 & -1 \\
\hline Usia 12 - 25 Tahun & -17 & -21 & -1 & 17 & -4 & 16 & 21 & 4 & 20 & 1 & -16 & -20 \\
\hline Usia 26 - 45 Tahun & -17 & -25 & -2 & 17 & -8 & 15 & 25 & 8 & 23 & 2 & -15 & -23 \\
\hline Usia 46 - 65 Tahun & -9 & -8 & -4 & 9 & 1 & 5 & 8 & -1 & 4 & 4 & -5 & -4 \\
\hline Usia $>65$ Tahun & -3 & 0 & -1 & 3 & 3 & 2 & 0 & -3 & -1 & 1 & -2 & 1 \\
\hline \multicolumn{13}{|l|}{ Jarak } \\
\hline Jarak Ke Posko Induk & 100 & -200 & -1000 & -100 & -300 & -1100 & 200 & 300 & -800 & 1000 & 1100 & 800 \\
\hline \multicolumn{13}{|l|}{ Kebutuhan Pokok } \\
\hline Makanan Usia > 12 Bulan & 0 & 0 & 0 & 0 & 0 & 0 & 0 & 0 & 0 & 0 & 0 & 0 \\
\hline
\end{tabular}

Pada penentuan nilai preferensi global digunakan persamaan (2). Berdasarkan persamaan tersebut, hasil yang diperoleh dapat dilihat pada tabel 7 .

Tabel 7. Nilai Preferensi Global

\begin{tabular}{|c|c|c|c|c|c|c|c|c|c|c|c|c|}
\hline \multirow[b]{2}{*}{ Kriteria } & \multicolumn{12}{|c|}{ Preferensi } \\
\hline & $\begin{array}{c}\mathrm{P} \\
(\mathrm{d}(1,2))\end{array}$ & $\begin{array}{c}\mathrm{P} \\
(\mathrm{d}(1,3))\end{array}$ & $\begin{array}{c}\mathrm{P} \\
(\mathrm{d}(1,4))\end{array}$ & $\begin{array}{c}\mathrm{P} \\
(\mathrm{d}(2,1))\end{array}$ & $\begin{array}{c}\mathrm{P} \\
(\mathrm{d}(2,3))\end{array}$ & $\begin{array}{c}\mathrm{P} \\
(\mathrm{d}(2,4))\end{array}$ & $\begin{array}{c}\mathrm{P} \\
(\mathrm{d}(3,1))\end{array}$ & $\begin{array}{c}\mathrm{P} \\
(\mathrm{d}(3,2))\end{array}$ & $\begin{array}{c}\mathrm{P} \\
(\mathrm{d}(3,4))\end{array}$ & $\begin{array}{c}\mathrm{P} \\
(\mathrm{d}(4,1))\end{array}$ & $\begin{array}{c}\mathrm{P} \\
(\mathrm{d}(4,2))\end{array}$ & $\begin{array}{c}\mathrm{P} \\
(\mathrm{d}(4,3))\end{array}$ \\
\hline \multicolumn{13}{|c|}{ Korban Berdasarkan Usia } \\
\hline Usia 1 - 5 Tahun & $-0,9046$ & 0,0000 & 0,0000 & 0,9046 & 0,9046 & 0,9046 & 0,0000 & $-0,9046$ & 0,0000 & 0,0000 & $-0,9046$ & 0,0000 \\
\hline Usia 12 - 25 Tahun & $-1,4664$ & $-1,8115$ & $-0,0863$ & 0,8626 & $-0,3450$ & 0,8626 & 0,8626 & 0,3450 & 0,8626 & 0,0863 & $-1,3802$ & $-1,7252$ \\
\hline Usia 26 - 45 Tahun & $-0,6577$ & $-0,9673$ & $-0,0774$ & 0,3869 & $-0,3095$ & 0,3869 & 0,3869 & 0,3095 & 0,3869 & 0,0774 & $-0,5804$ & $-0,8899$ \\
\hline Usia 46 - 65 Tahun & $-0,3834$ & $-0,3408$ & $-0,1704$ & 0,3834 & 0,0426 & 0,2130 & 0,3408 & $-0,0426$ & 0,1704 & 0,1704 & $-0,2130$ & $-0,1704$ \\
\hline Usia $>65$ Tahun & 0,0881 & $-0,0881$ & 0,0000 & $-0,0881$ & $-0,1761$ & $-0,0881$ & 0,0881 & 0,1761 & 0,0881 & 0,0000 & 0,0881 & $-0,0881$ \\
\hline Usia 6 - 11 Tahun & $-0,4248$ & 0,0000 & $-0,1416$ & 0,4248 & 0,4248 & 0,2832 & 0,0000 & $-0,4248$ & $-0,1416$ & 0,1416 & $-0,2832$ & 0,1416 \\
\hline \multicolumn{13}{|l|}{\begin{tabular}{|l|} 
Jarak \\
\end{tabular}} \\
\hline Jarak Ke Posko Induk & 0.6521 & 1.1737 & 1.1737 & 1.1737 & 1.1737 & 1.1737 & 1.3041 & 0 & 1.1737 & 0 & 0 & 0 \\
\hline \multicolumn{13}{|l|}{ Kebutuhan Pokok } \\
\hline Makanan Usia > 12 Bulan & 2.86 & 2.86 & 2.86 & 2.86 & 2.86 & 2.86 & 2.86 & 2.86 & 2.86 & 2.86 & 2.86 & 2.86 \\
\hline $\operatorname{Pg}(\operatorname{dj}(\mathrm{a}, \mathrm{b}))$ & $-0,0296$ & 0,1033 & 0,4448 & 0,8635 & 0,5719 & 0,8245 & 0,7303 & 0,2898 & 0,6750 & 0,4170 & $-0,0517$ & $-0,0160$ \\
\hline
\end{tabular}

Tahapan selanjutnya adalah menghitung leaving flow dan entering flow menggunakan persamaan (3) dan (4). Kemudian menghitung net flow yang akan menjadi penentu posko prioritas dengan menggunakan persamaan
(5). Tabel 8 adalah leaving flow, entering flow, dan net flow yang diperoleh dari persemaan tersebut. 
Tabel 8. Urutan Posko Prioritas Dengan Untuk Distribusi Makanan Usia Lebih Dari 1 Tahun.

\begin{tabular}{|l|c|c|c|}
\hline \multicolumn{1}{|c|}{ Posko } & Leaving Flow & Entering Flow & Net Flow \\
\hline Posko II & 0,0695 & 0,7533 & 0,6838 \\
\hline Posko III & 0,2304 & 0,5650 & 0,3347 \\
\hline Posko I & 0,6703 & 0,1728 & $-0,4974$ \\
\hline Posko IV & 0,6481 & 0,1271 & $-0,5210$ \\
\hline
\end{tabular}

Berdasarkan hasil net flow di atas, maka posko prioritas untuk pendistribusian makanan usia lebih dari 1 tahun adalah Posko II yaitu Dusuh Timboro’ Desa Arah dengan net flow sebesar 0,6838 .

\subsection{Pengujian Akurasi Sistem Dengan Confusion Matrix}

Data yang digunakan untuk pengujian confusion matrix ini adalah data-data yang diperoleh dari BPBD Kabupaten Gowa. Tabel 9 adalah tabel perbandingan pengujian hasil dari sistem dan hasil yang diperoleh secara manual

Tabel 9. Data Pengujian Hasil Sistem Dan Hasil

\begin{tabular}{|c|c|c|c|c|}
\hline \multicolumn{5}{|c|}{ Manual } \\
\hline No & $\begin{array}{l}\text { Hasil } \\
\text { Manual }\end{array}$ & $\begin{array}{l}\text { Hasil } \\
\text { Sistem }\end{array}$ & TRUE & FALSE \\
\hline 1 & Posko II & Posko II & $\sqrt{ }$ & \\
\hline 2 & Posko II & Posko II & $\sqrt{ }$ & \\
\hline 3 & Posko II & Posko II & $\sqrt{ }$ & \\
\hline 4 & Posko II & Posko II & $\sqrt{ }$ & \\
\hline 5 & Posko III & Posko III & $\sqrt{ }$ & \\
\hline 6 & Posko III & Posko III & $\sqrt{ }$ & \\
\hline 7 & Posko II & Posko II & $\sqrt{ }$ & \\
\hline 8 & Posko II & Posko II & $\sqrt{ }$ & \\
\hline 9 & Posko III & Posko II & & $\sqrt{ }$ \\
\hline 10 & Posko III & Posko III & $\sqrt{ }$ & \\
\hline 11 & Posko II & Posko II & $\sqrt{ }$ & \\
\hline 12 & Posko III & Posko III & $\sqrt{ }$ & \\
\hline 13 & Posko II & Posko II & $\sqrt{ }$ & \\
\hline 14 & Posko III & Posko II & & $\sqrt{ }$ \\
\hline 15 & Posko III & Posko III & $\sqrt{ }$ & \\
\hline 16 & Posko II & Posko II & $\sqrt{ }$ & \\
\hline TOTAI & 14 & 2 & & \\
\hline
\end{tabular}

Data pengujian hasil sistem dan hasil secara manual pada tabel 9 kemudian akan digunakan pada pengujian confusion matrix sesuai pada tabel 10 :

Tabel 10. Pengujian Confusion Matrix

\begin{tabular}{|c|c|c|c|}
\hline \multirow{2}{*}{\multicolumn{2}{|c|}{ Identifikasi }} & \multicolumn{2}{|c|}{ Predicted Class } \\
\hline & & True & False \\
\hline \multirow{2}{*}{$\begin{array}{c}\text { Actual } \\
\text { Class }\end{array}$} & True & 14 & 2 \\
\hline & False & 0 & 0 \\
\hline
\end{tabular}

Untuk menentukan akurasi sistem digunakan persamaan (6) dengan data yang diambil pada tabel 10 .

Accuracy $=((\mathrm{TP}+\mathrm{TN}) /(\mathrm{TP}+\mathrm{FN}+\mathrm{FP}+\mathrm{TN})) \times 100 \%$

Accuracy $=((14+0) /(14+2+0+0) \times 100 \%$

Accuracy $=(14 / 16) \times 100 \%=87,5 \%$.
Berdasarkan persamaan (6) tersebut diperoleh akurasi $87,5 \%$.

\subsection{User Interface Sistem}

Sistem penentuan prioritas pendistribusian bantuan logistik bencana alam memiliki 3 aktor yaitu admin posko induk, admin posko lapangan, dan user biasa.

1. Admin posko induk.

Admin posko induk selain melakukan pendistribusian bantuan juga bertindak sebagai administrator sistem seperti melakukan update dan delete data master yang di dalamnya terdapat data kriteria, sub kriteria, data posko, data barang, dan data kategori barang, melakukan update pemasukan item bantuan, update dan delete data korban baik yang ada di posko induk maupun di posko lapangan, update pengeluaran item bantuan, dan melakukan pengaturan awal kriteria penentuan prioritas pendistribusian bantuan logistik bencana alam seperti menentukan min/max dan juga threshold masing-masing sub kriteria. User interface admin posko induk dapat dilihat pada Gambar 2.

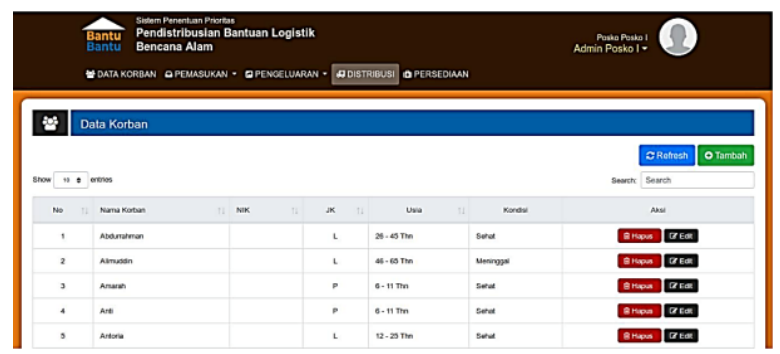

Gambar 2. Halaman admin posko induk

2. Admin posko lapangan.

Admin posko lapangan hanya bertindak sebagai penerima bantuan logistik dan melakukan update persediaan berdasarkan posko masing-masing. User interface admin posko induk dapat dilihat pada Gambar 3.

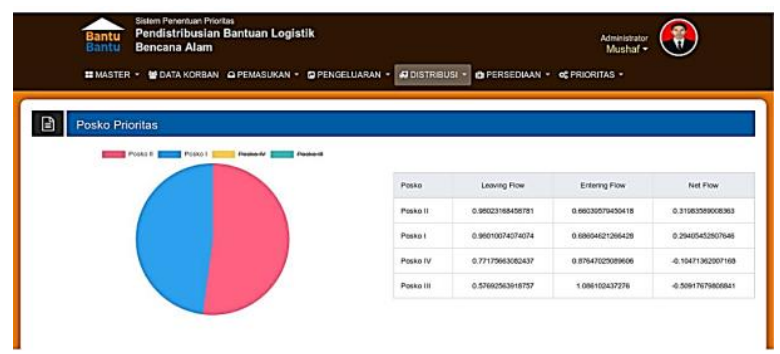

Gambar 3. Halaman admin posko lapangan

3. User Biasa.

User biasa atau masyarakat umum dapat melihat data korban dan data bantuan pada posko lapangan yang memungkinkan adanya parameter untuk masyarakat dalam menentukan bantuan yang akan diberikan. User interface admin posko induk dapat dilihat pada Gambar 4. 


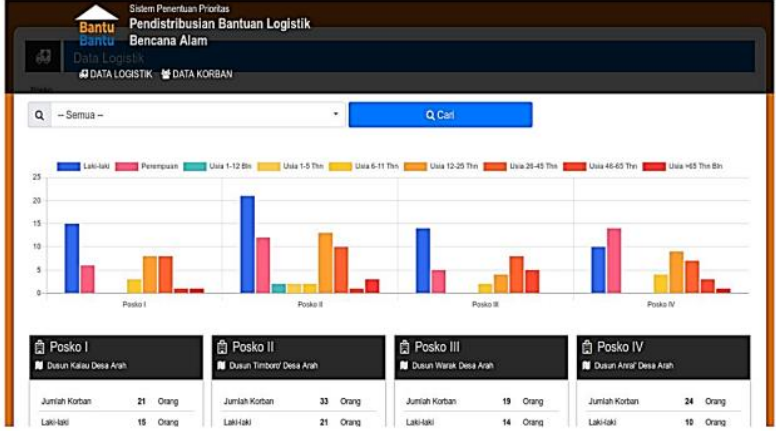

Gambar 4. Halaman user biasa

\section{KESIMPULAN}

Pada penelitian ini terdapat 6 kriteria distribusi bantuan logistik bencana alam yaitu korban berdasarkan jenis kelamin, korban berdasarkan usia, korban berdasarkan kondisi, jarak, kebutuhan pokok, kebutuhan sekunder, dan relawan. Kemudian terdapat 31 sub kriteria yang dibutuhkan dalam penentuan prioritas bantuan logistik bencana alam yaitu pada tabel 4 .

Kombinasi metode ANP dan Promethee sangat cocok untuk kasus pendistribusian bantuan logistik bencana alam dimana alternatif dan kriteria pada kasus ini memiliki data kuantitatif dan kualitatif sekaligus. Untuk perhitungan metode ANP dan Promethee pada penelitian ini digunakan contoh kasus pendistribusian makanan untuk usia lebih dari 1 tahun. Dari hasil perhitungan data-data alternatif dan kriteria diperoleh nilai net flow untuk posko I adalah-0,4974 posko II adalah 0,6838, posko III adalah 0,3347, dan posko IV adalah sebesar 0,5210 .

Metode confusion matrix digunakan untuk pengujian sistem pada penelitian ini. Dari 16 kali percobaan dengan kasus pendistribusian bantuan logistik yang berbeda diperoleh akurasi sebesar 87,5\%.

\section{SARAN}

Untuk perbaikan dan pengembangan sistem pada penelitian selanjutnya, diharapkan adanya peningkatan akurasi pada sistem ini. Sistem ini juga masih kurang untuk menangani kasus pendistribusian obat-obatan sehingga perlu dilakukan penelitian lebih lanjut terkait pendistribusian obat-obatan untuk membantu tenaga medis dalam mengelola bantuan obat-obatan pasca bencana alam

\section{DAFTAR PUSTAKA}

Aji, M. R. (2018) Tiga Kendala Ini Hambat Distribusi Bantuan Pengungsi Gempa Lombok, Tempo.co. Available at: https://nasional.tempo.co/read/1119632/tigakendala-ini-hambat-distribusi-bantuan-pengungsigempa-lombok/full\&view $=$ ok .

Anam, A. K., Winarni, S., and Andriani, S. R. (2017) 'The Role of Volunteers in Mount Kelud Eruption
Disaster Management', Jurnal Informasi Kesehatan Indonesia (JIKI), 3(1), p. 1.

Apriliani, D. and Somantri, O. (2019) 'Implementasi Metode Promethee Dalam Sistem Pendukung Keputusan Penilaian Raport Dosen', Jurnal Informatika: Jurnal Pengembangan IT, 4(1), pp. 38-42. doi: 10.30591/jpit.v4i1.1251.

Azhar, A. H. and Destari, R. A. (2019) 'Optimasi Decision Support System ( DSS ) Pemilihan Paket Layanan Internet Prabayar Dengan Metode ANP', 3(September), pp. 183-192.

BNPB. (2014) 'Penanggulangan Bencana Pedoman', Berita Negara Republik Indonesia, (1422), pp. 8 35. Available at: https://bnpb.go.id/

BNPB (2019) Bencana Alam Di Indonesia Tahun 2016 $S / D$ 2018. Available at https://dibi.bnpb.cloud/tabella.

Dewi, K. dkk. (2018) 'Sistem Pendukung Keputusan Penyusunan Prioritas Perbaikan Standar Akreditasi Program Studi Menggunakan Metode AHP dan', 1(1), pp. 45-54.

Fadlan, M., Muhammad, M. and, H. (2017) 'Terapan Kombinasi Metode TOPSIS DAN Analytical Hierarcy Process Pada Perekomendasian Penerima Beasiswa Peningkatan Prestasi Akademik (Studi Kasus pada STMIK PPKIA Tarakanita Rahmawati)', Simetris : Jurnal Teknik Mesin, Elektro dan Ilmu Komputer, 8(2), p. 663. doi: 10.24176/simet.v8i2.1565.

Farid, A. M. dkk. (2019) 'Pemilihan Alternatif Lokasi Baru CV. Cahya Saudara dengan Metode Promethee', 1(2).

Firmanto, B. (2016) 'Penggunaan Algoritma Promethee Untuk Pemilihan Guru Teladan Tingkat Smu Dan Smk', Jurnal Ilmu-Ilmu Teknik - Sistem, 12(1), pp. $48-54$.

Ningsih, S. R. and Windarto, A. P. (2018) 'Penerapan Metode Promethee II pada Dosen Penerima Hibah P2M Internal', InfoTekJar (Jurnal Nasional Informatika dan Teknologi Jaringan), 3(1), pp. 20-25. doi: 10.30743/infotekjar.v3i1.641.

Nugraha, R. A. and Cholissodin, I. (2018) 'Implementasi Metode Analytic Hierarchy Process - Weighted Product Untuk Rekomendasi Hunian Ideal ( Studi Kasus: Kota Malang )', Jurnal Pengembangan Teknologi Informasi dan Ilmu Komputer ( $J$ PTIIK) Universitas Brawijaya, 2(2), pp. 848-856.

Polinema, J. I. dkk. (2018) 'Pengembangan Aplikasi Pemilihan Kost Di Kota Malang Dengan Metode AHP Dan Promethee', 1, pp. 229-234.

Ranti, N. dkk. (2020) 'Analisis Penentuan Penginapan dengan Metode AHP dan Promethee', 02, pp. 173-179.

Saikin, S. and Kusrini, K. (2019) 'Model Data Mining Untuk Karekteristik Data Traveller Pada Perusahaan Tour and Travel', Jurnal Manajemen Informatika dan Sistem Informasi, 2(2), p. 61. doi: $10.36595 /$ misi.v2i2.105. 
Siregar, J. (2017) 'Sistem Pendukung Keputusan Penentuan Prioritas Wilayah Pengawasan Perikanan (WPP-711) Menggunakan Metode AHP-TOPSIS', Pelita Informatika Budi Darma, 8(3), pp. 167-171.

Sumiyatun, S. and Wardoyo, R. (2016) 'Kombinasi Metode Anp Dan Topsis Dalam Menentukan Prioritas Media Promosi Perguruan Tinggi (Studi Kasus: Stmik Akakom Yogyakarta)', JIKO (Jurnal Informatika dan Komputer), 1(2), pp. 2127. doi: 10.26798/jiko.2016.v1i2.34.

Utomo, M. H. dkk. (2016) 'Perilaku Menolong Relawan Spontan Bencana Alam', 2(1), pp. 48-59. 